\title{
Pediatrik Hastada Amoksisilin-Klavulanik Asit Kullanımı Sonrası Gelişen Lingua Villosa Nigra: Olgu Sunumu
}

\section{Lingua Villosa Nigra Developing After Amoxicillin-Clavulanic Acid Use in a Pediatric Patient: A Case Report}

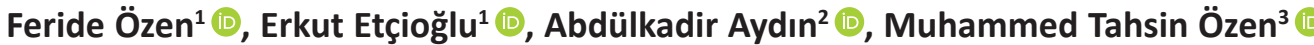

\author{
${ }^{1}$ Sakarya Üniversitesi Tıp Fakültesi, Aile Hekimliği Anabilim Dalı, Sakarya, Türkiye \\ ${ }^{2}$ Sakarya Üniversitesi Eğitim ve Araştırma Hastanesi, Aile Hekimliği Kliniği, Sakarya, Türkiye \\ ${ }^{3}$ Sağlık Bilimleri Üniversitesi Kocaeli Derince Eğitim ve Araştırma Hastanesi, Acil Tıp Kliniği, Kocaeli, Türkiye
}

ORCID ID: F.Ö. 0000-0003-0009-4433; E.E. 0000-0002-8117-7929; A.A. 0000-0003-0663-586X; M.T.Ö. 0000-0002-6000-528X

Citation/Attf: Ozen F, Etcioglu E, Aydin A, Ozen MT. Pediatrik hastada amoksisilin-klavulanik asit kullanımı sonrası gelişen lingua villosa nigra: Olgu sunumu. Çocuk Dergisi - Journal of Child 2021;21(2):218-220. https://doi.org/10.26650/jchild.2021.832942

öz

Siyah kıllı dil (lingua villosa nigra), dil dorsumunun arka tarafında deskuamasyon kusuru ve dilin filiform papillalarında reaktif hipertrofi ile karakterize olan, ağrısız, kendini sınırlayan ve benign özelliklere sahip klinik bir durumdur. Etiyopatogenez net olarak bilinmemekle beraber bazı ilaçların kullanımı, kötü ağız bakımı, sigara/alkol tüketimi, aşırı siyah çay ve kahve tüketimi etiyolojide yer alan nedenler arasında gösterilmektedir. Siyah kıllı dil erişkin popülasyona oranla pediatrik yaş grubunda daha nadir görülür. Bu yazıda pediatrik hastada amoksisilin-klavulanik asit kullanımı sonrası gelişen siyah kıllı dil olgusu sunmaktayız.

Anahtar Kelimeler: Lingua villosa nigra, çocuk, amoksisilin-klavulanik asit

\section{Giriş}

Siyah kıllı dil (lingua villosa nigra), dil dorsumunun arka tarafinda deskuamasyon kusuru ve dilin filiform papillalarında reaktif hipertrofi ile karakterize olan, ağrısız özellikte olan klinik durumdur (1). Kıllı dil sıklıkla kendini sınırlayan benign bir lezyon olup, kahverengi, sarı, yeşil, mavi hatta pigmentsiz şekilde de görülebilmektedir $(1,2)$.

Etiyopatogenez net olarak bilinmemekle beraber; linezolid, ranitidin, metronidazol, lansoprozol, sefiksim, sülbaktam ve ampisilin gibi bazı ilaçların kullanımı bu duruma yol açan nedenler arasında gösterilmektedir (2).

Siyah kıllı dil prevelansı ülkeler arasında \%0.6 ile \%11.3 arasında değişmektedir. Sıklıkla erişkin hastalarda görülmesinin yanında
ABSTRACT

Black hairy tongue (lingua villosa nigra) is a painless, self-limiting and benign clinical condition characterized by a desquamation defect in the posterior part of the tongue dorsum and reactive hypertrophy of the filiform papillae of the tongue. Although the etiopathogenesis is not clearly known, the use of some drugs, poor oral care, smoking / alcohol consumption, and excessive black tea and coffee consumption are among the causes in the etiology. Black hairy tongue is less common in pediatric patients than in the adult population. In this article, we present a case of black hairy tongue that developed after the use of amoxicillin-clavulanic acid in a pediatric patient.

Keywords: Lingua villosa nigra, child, amoxicillin-clavulanic acid

çocuklarda daha nadirdir (3).

Bu yazıda pediatrik hastada amoksisilin-klavulanik asit kullanımı sonrası gelişen siyah kıllı dil olgusu sunulacaktır.

Hastanın yasal temsilcisinden tıbbi verilerinin yayınlanabileceğine dair yazılı onam alınmıştır.

\section{OLGU}

On sekiz aylık erkek hasta, polikliniğimize son 2 gündür dilinde siyah renk değişikliği ile başvurdu. Tıbbi öyküsünde hastanın 12 gün önce alt solunum yolu enfeksiyonu nedeniyle 10 gün süreyle $80-90 \mathrm{mg} / \mathrm{kg} /$ gün $2 \times 1$ pozolojisinde amoksisilinklavulanik asit peroral (PO) yoldan kullandığı belirtildi.

Sorumlu Yazar/Corresponding Author: Feride Özen E-mail: drferideuysal@gmail.com

Başvuru/Submitted: 29.11.2020 • Revizyon Talebi/Revision Requested: 09.08.2021 • Son Revizyon/Last Revision Received: 11.08 .2021 • Kabul/Accepted: 16.08 .2021 
Fizik muayenesinde; hafif ağız kokusu ve dilin dorsal yüzünde kahverengi/siyah renk değişikliği haricinde belirgin bir özellik saptanmadı. Prenatal ve postnatal dönemde özellik yoktu. Doğum; miadında, 3000 gr, C/S olarak gerçekleşmiş olan hastanın soygeçmişinde özellik saptanmadı. Anne ve baba; sağ, sağlıklı özgeçmişlerinde özellik saptanmadı. Olgunun ailenin tek çocuğu olduğu belirtildi.

Laboratuvar incelemesinde C-reaktif protein (CRP), tam kan sayımı ve biyokimyasal testler hastanın yaşına göre normal aralıkta saptandı. Bu bulgular eşliğinde hastaya amoksisilin -klavulanik asit kullanımı sonrası gelişen siyah kıllı dil tanısı koyuldu.

Hastanın dilinin dorsal yüzeyinin yumuşak diş fırçasıyla günde 3-4 kez firçalayarak temizlenmesi önerildi. Hastanın kontrollerinde şikayetinin 2 hafta içerisinde tamamen gerilediği ve dil yüzeyinde herhangi bir lezyon kalmadığı görüldü.

Şekil 1'de hastanın başvuru sırasındaki ve tedavinin 14 . günündeki dil görüntüsü sunulmuştur.

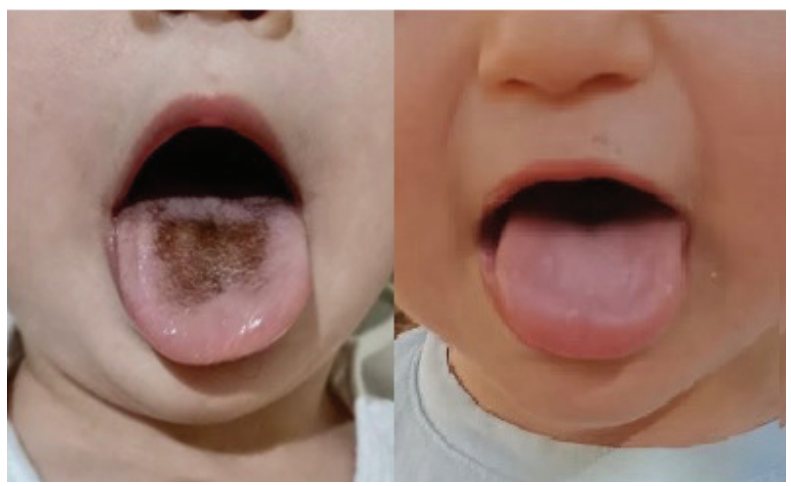

Şekil 1: Hastanın başvuru sırasındaki ve tedavi sonrası 14. gündeki dil görüntüsü

\section{TARTIŞMA}

Siyah kıllı dil gelişiminde birçok etken rol oynamaktadır. Kötü ağız hijyeni, çeşitli yiyecek ve içeceklerin tüketimi, sigara ve alkol tüketimi siyah kıllı dil gelişimine yol açtı̆̆ gibi terapötik amaçlı kullanılan bazı ilaçların yan etkisi olarak da ortaya çıkabilmektedir. Hindistan'da yapılan bir olgu sunumunda 10 yaşındaki erkek hastada linezolid kullanımı sonrası siyah kıllı dil gelişimi bildirilmiştir (4). Türkiye'de yapılmış bir yayında 4 aylık kız hastada Kocuria (Micrococcus) kristinae bakteriyemisine bağlı siyah kıllı dil olgusu bildirilmiştir (5). Akcaboy ve arkadaşları yaptıkları bir olgu sunumunda ise gastroösofageal reflü tedavisi nedeniyle ranitidin tedavisi gören 3 yaşında kız hastanın dilinin dorsal yüzeyinde tedavinin 14 . gününden itibaren siyah renk değişimi başladığı bildirmişler ve tedavinin kesilmesinin ardından 4 hafta içerisinde tamamen düzeldiğini belirtmişlerdir (6). Hastamızın tıbbi öyküsünden, başvurusundan 12 gün önce alt solunum yolu enfeksiyonu nedeniyle 10 gün boyunca amoksisilin-klavulanik asit tedavisi gördüğü öğrenilmiştir.
Literatürde siyah kıllı dil görülen en genç olgu sıklıkla mama ile beslenmekte olan 2 haftalık yenidoğan bebek olarak bildirilmiştir (7). İspanyada yayınlanan bir olgu sunumunda ise; 66 yaşında erkek hastada amoksisilin-klavulanik asit kullanımı sonrası dilde mavi-siyah renk değişikliği olduğu bildirilmiş olup, hastanın kronik sigara içicisi olduğu belirtilmiştir (8). Hastamız 18 aylık olup, siyah dil oluşumunu indükleyen etkenin amoksisilin-klavulanik asit olduğu düşünülmüştür.

Tedavi şemasında ilk basamakta dilin dorsal yüzünün günlük olarak firçalanarak ağız hijyeninin sağlanması vardır. Fırçalama işlemi, lezyonun ve uzamış olan papillaların mekanik olarak kürete edilmesini ve yeni papillaların oluşmasını sağlamaktadır. Tedavide önerilen diğer seçenekler ise topikal triamsinolon asetat, vitamin B komplekslerinin kullanılması ve dil üzerinin her gün $\% 0.1$ veya $\% 0.025$ oranında tretinoin ile firçalanması ve 5 dakika sonrasında durulanmasıdır (9). Dil üzerinde herhangi bir bakteri veya mantar tespit edildiyse antibakteriyal ve antikandidiyal ajanlar kullanılabilmektedir (2). Hastamızın dilindeki renk değişikliği dilin dorsal yüzünün günde 3-4 kez firçalanmasıyla 14 gün içerisinde tamamen iyileşmiştir.

\section{SONUÇ}

Pediatrik popülasyonda sıklıkla kullanılmakta olan amoksisilinklavulanik asidin bir yan etki olarak siyah kıllı dile neden olması dikkat çekicidir. Bu ilacın kullanımına bağlı gelişebilen bu yan etki ve tedavi şeması klinisyenler tarafindan mutlaka akılda tutulmalıdır.

Bilgilendirilmiş Onam: Katılımcılardan bilgilendirilmiş onam alınmıştır.

Hakem Değerlendirmesi: Dış bağımsız.

Yazar Katkıları: Çalışma Konsepti/Tasarım- F.Ö., E.E., A.A., M.T.Ö.; Veri Toplama- F.Ö., E.E., A.A., M.T.Ö.; Veri Analizi/Yorumlama- F.Ö., E.E., A.A., M.T.Ö.; Yazı Taslağı- F.Ö., E.E., A.A., M.T.Ö.; İçeriğin Eleştirel İncelemesiF.Ö., E.E., A.A., M.T.Ö.; Son Onay ve Sorumluluk- F.Ö., E.E., A.A., M.T.Ö.

Çıkar Çatışması: Yazarlar çıkar çatışması beyan etmemişlerdir.

Finansal Destek: Yazarlar finansal destek beyan etmemişlerdir.

Informed Consent: Written consent was obtained from the participants.

Peer Review: Externally peer-reviewed.

Author Contributions: Conception/Design of Study- F.Ö., E.E., A.A., M.T.Ö.; Data Acquisition- F.Ö., E.E., A.A., M.T.Ö.; Data Analysis/ Interpretation- F.Ö., E.E., A.A., M.T.Ö.; Drafting Manuscript- F.Ö., E.E., A.A., M.T.Ö.; Critical Revision of Manuscript- F.Ö., E.E., A.A., M.T.Ö.; Final Approval and Accountability- F.Ö., E.E., A.A., M.T.Ö.

Conflict of Interest: Authors declared no conflict of interest.

Financial Disclosure: Authors declared no financial support. 


\section{KAYNAKLAR/REFERENCES}

1. Gurvits GE, Tan A. Black hairy tongue syndrome. World J Gastroenterol 2014;20:10845-50.

2. Özçiftçi Ertuğral N, Ergin H. 9 Yaşında Bir Çocuk Hastada Gelişen Siyah Kıllı Dil (Lingua Villosa Nigra): Olgu Sunumu. Uludağ Üniversitesi Tıp Fakültesi Dergisi 2019;45(2):215-7.

3. Avcu N, Kanli A. The prevalence of tongue lesions in 5150 Turkish dental outpatients. Oral Dis 2003;9:188-95.

4. Maharani B, Parthasarathi, T, Ravichandran V, Balaji G. Linezolid induced black hairy tongue.Indian Journal of Pharmacology 2014; 46(6):653. doi:10.4103/0253-7613.144942.

5. Oncel EK, Boyraz MS, Kara A. Black tongue associated with Kocuria (Micrococcus) kristinae bacteremia in a 4-month-old infant. European Journal of Pediatrics 2011;171(3):593. doi:10.1007/ s00431-011-1573-8.
6. Akcaboy M, Sahin S, Zorlu P, Şenel S. Ranitidine-induced black tongue: A case report. Pediatric Dermatology 2017;34(6):e334e336. doi:10.1111/pde.13309

7. Schwartz RH, Lee T. A Two-Week-Old Term Baby With a Black Tongue. Clinical Pediatrics 2014;54(11):1110-2. doi:10.1177/0009922814561354.

8. López-Martín I, García-Martínez FJ, Benito Ortiz L, Toribio J. Lengua negra vellosa. Medicina Clínica 2013;141(5):e9. doi:10.1016/j. medcli.2013.03.004

9. Langtry J, Carr M, Steele M, Ive F. Topical Tretinoin: a new treatment for black hairy tongue (Lingua Villosa Nigra). Clin Exp Dermatol 1992;17:163-4. 